UDC 78.072

DOI 10.33287/221934

Радзецький Юрій Володимирович, викладач кафедри ,НАародні інструменти” Дніпропетровської академії музики ім. М. Глінки

тел. (097) $241-52$ - 15

e-mail: academyglinka@meta.ua

\title{
ФЕСТИВАЛІ ЮВІЛЕЇВ У ДНІПРІ (класична гітара)
}

Ціль гітарних фестивалів-ювілеїв - пошук та затвердження нових форм дієвого впорядковування, а також узагальнення репертуарної й методичної спадщини у широкій галузі класичної гітарної музики, з максимально точною відповідністю первинному значенню поняття „Ювілей”.

Вінченцо Галілей та Луїс де Нарваєс, Джон Доуленд i Франческо Корбета, Філіппо Гран'яні й Франческо Моліно, Василь Саренко, а також Антоніо Лауро, Джон Дюарт й, безперечно, Олександр Іванов-Крамський, - всіх цих постатей класичної гітарної музики, розділених й у часі, й у просторі поєднує приналежність саме до ювілеїв, що відзначались в другому десятилітті двотисячних років. Усі перераховані ювіляри вшановувались яскравими фестивалями академічної гітари в 2012 - 2019 роках у Дніпропетровській академії музики ім. М. Глінки.

Фестивалі Ювілеїв припускали і спробу впорядковування й узагальнення п'ятисотрічної історії щодо розвитку виконавства на класичній гітарі. Наголосимо, що п’ять Фестивалів Ювілеїв охопили, практично всі технологічно-стильові різновиди інструментарію та репертуару.

Перший фестиваль-ювілей був присвячений сторіччю із дня народження Олександра Іванова-Крамського (2012 р.). Фестиваль відкрився двогодинним концертом знаного гітариста, лауреата багатьох міжнародних конкурсів Валерія Агабабова із Москви. Запрошення саме цього музиканта було не випадковим, адже якраз Валерій Павлович особисто знав ювіляра й неодноразово відвідував його концерти, та сьогодні ще і співпрацює, як викладач, із донькою Олександра Іванова-Крамського, - а саме - Наталією Івановою- 
Крамською у Московському державному інституті мистецтв. Зазначена програма концерту була складена із творів, обробок та п'єс репертуару Олександра Іванова-Крамського.

Другий день свята музики розпочався із конкурсних прослуховувань. Було заявлено більше ніж сорок учасників 3 Дніпропетровська, Кривого Рога, а також Павлограда, Новомосковська й інших міст області. Спочатку змагались вихованці дитячих музичних шкіл. Переможцем, за рішенням журі, стала учениця 5 класу Криворізької музичної школи № 13 Тетяна Чайка. У конкурсі зі студентів вищих навчальних закладів перемогу здобув студент III курсу з Дніпропетровського музичного училища Микита Лосєв. Треба відзначити, що у конкурсних прослуховуваннях звучала музика лише Іванова-Крамського.

Класичні гітари, що були представлені на фестивалі київською компанією „Real Music”, суттєво поширили знання слухачів й відвідувачів фестивалю щодо сучасних технологій виготовлення інструментів. Були представлені класичні гітари японо-іспанської фірми „Арія”. Демонстрував якості та можливості інструментів вихованець Дніпропетровського музичного училища ім. М. Глінки Дмитро Радзецький.

У вечірньому концерті звучали найрізноманітніші композиції зі спадщини Олександра Іванова-Крамського: це й маленькі нескладні твори для починаючих гітаристів, що були виконані учнями ЦМШ Асею Федотовою, Артуром Кабро та Іваном Огойко. Більш розгорнуті п'єси й обробки ювіляра прозвучали в інтерпретації Дмитра Ваксера, Микити Лосєва й Євгена Григоровича. А особливою прикрасою вечора була прем'єра 2-х концертів для гітари $з$ оркестром Олександра Іванова-Крамського, які виразно виконали Дарина Черниш (гітара) й Галина Ушакова (фортепіано).

У третій день Фестивалю пройшла творча зустріч 3 гостем, гітаристом Валерієм Агабабовим. Він представив особисті нотні збірки, презентував власні композиції, обробки й переклади класичних творів для шестиструнної гітари. Також Валерій Агабабов провів майстер-клас зі студентом музичного училища Павлом Пакшиним. Фестиваль завершився яскравим нагородженням переможців конкурсу, врученням дипломів та спеціально підготовленого цифрового видання „Олександр Іванов-Крамський. Антологія". 


\section{Другий фестиваль-ювілей був присвячений 450-річчю від} дня народження англійського лютняра й композитора Джона Доуленда (2013 р.). 9 грудня у концертній залі Дніпропетровської консерваторії ім. М. Глінки зібрались шанувальники як лютневої, так і гітарної музики, численні поціновувачі творчості славетного англійського лютняра, композитора, а також поета XVI - XVII століть, доброго товариша Вільяма Шекспіра - Джона Доуленда. Фестиваль розпочався концертом відомого гітариста і лютняра, доктора університету з Айови (США) Олега Тімофєєва. Запрошення цього виконавця було не випадковим. Олег Віталійович знаний фахівець у сфері стародавньої лютневої музики, іiі стилістики й методики виконання, також i викладання. Програма спеціально підготовленого до виступу в Дніпропетровську концертного історично-музичного представлення була сформована переважно 3 композицій Джона Доуленда i його сучасників та митців співвітчизників.

Наступний день фестивалю відкрився 3 конкурсних прослуховувань. Було заявлено більше ніж тридцять учасників 3 міст Дніпропетровська, Дніпродзержинська, а також Кривого Рогу, Павлограда й Новомосковська. Спочатку змагались вихованці дитячих музичних шкіл й навчальних закладів естетичного виховання. Переможцем, за одностайним рішенням журі під головуванням Олега Тімофєєва, став Ернест Сирота 3 Дніпродзержинська. У конкурсі серед багатьох студентів вищих навчальних закладів першу премію отримав Дмитро Ваксер. Треба відзначити, що у конкурсних прослуховуваннях лунала музика лише Джона Доуленда. Обов’язковими були „Зимова жига” та „Фантазія”, а другим, повинен був виконуватись довільно обраний твір 3 максимально величезної гітарної спадщини того ж видатного Джона Доуленда.

У вечірньому концерті були яскраво представлені найрізноманітніші композиції. Це й маленькі дидактичні вправи, своєрідні етюди для починаючих 3 навчально-методичного видання Джона Доуленда та його сина-музиканта Роберта 1610 року „Посібник гри на лютні”, численні переклади фантазій, посвят й танців для дуету і тріо гітаристів, а також вокальні твори Джона Доуленда у неперевершеному виконанні Маріанни Рябошлик із супроводом студентів класу гітари. 
Ще однією з прикрас цього вечора була прем’єра характерного циклу обробок пісень Джона Доуленда для інструментального дуету, який, наголосимо, спеціально підготували до фестивального концерту блискуча флейтистка Аріна Шапочкіна (асистент-стажист Національної музичної академії України ім. П.І. Чайковського) і випускник Дніпропетровського музичного училища ім. М. Глінки Дмитро Радзецький.

У заключний день фестивалю відбулась плідна, змістовна й винятково творча зустріч 3 нашим гостем, доктором університету 3 Айови (США) Олегом Тімофєєвим. Розповідь про своєрідності й стилістику виконання ренесансної, а також барочної музики на лютні, власні вагомі творчі доробки й досягнення, які Олег Віталійович залюбки ілюстрував демонстрацією аудіо-записів, були надзвичайно корисними для численних слухачів. Також зазнали проведення показові майстер-класи, підкреслимо, на матеріалі обов'язкових конкурсних творів: „Зимова жига” та „Фантазія” e-moll Джона Доуленда.

Не можна оминути увагою, що вже в друге у наших заходах брала участь та суттєво допомагала призами й сувенірами київська компанія „Реал Мюзік” та їі провідний фахівець Олексій Івченко, який докладно розповів про ситуацію, щодо перспективних заходів у галузі академічної гітарної музики, які плануються компанією на наступний 2014 рік.

Завершився фестиваль яскравим урочистим нагородженням переможців і призерів конкурсу, а саме - врученням дипломів, призів, сувенірів й спеціально підготовленого до фестивалю якісного цифрового видання „Джон Доуленд. Антологія”. До диску також увійшли відео й аудіо записи, біографічні довідки, портрети і ноти 3 творами Джона Доуленда.

Третій фестиваль ювілеїв класичної гітарної музики (2015 р.). Цей Фестиваль Ювілеїв був присвячений багатогранній творчості видатного іспанського віуеліста, викладача, відомого композитора XVI століття Луїса де Нарваєса, французького барочного гітариста Франческо Корбети, а також семиструнника Василя Саренка.

Відкриття постало своєрідною естафетою від 2-х попередніх фестивалів, що були присвячені Олександру Іванову-Крамському й англійському лютняру Джону Доуленду. 
3 блискавично-яскравою „Тарантелою” Іванова-Крамського виступив студент училища Павло Пакшин, напрочуд меланхолійна „Канцона” Джона Доуленда лунала у виконанні дуету учнів центральної музичної школи Івана Огойка й Кирила Романька. Завершив цю винятково цікаву й художньо довершену невеличку музичну естафету виступ ансамблю гітаристів 3 дванадцятої дніпропетровської дитячої музичної школи, яким керує Олександр Гарник.

Після цього на велику сцену вийшов лауреат престижних міжнародних конкурсів, знаний французький гітарист Філіп Віла. Його насичений та стилістично різноманітний концерт плідно тривав більше двох годин. Виступ був складений із творів барочної, класичної, а також сучасної академічної музики. Не оминув увагою гість фестивалю й ювілярів - художньо виразно прозвучала „Прелюдія” Франческо Корбети й „Український танець” Василя Саренка.

Наступний день Фестивалю розпочався, що вже традиційно, 3 конкурсних прослуховувань. Було заявлено більше ніж тридцяти учасників із Дніпропетровська, Кривого Рога, а також Павлограда, Новомосковська й інших міст. Спочатку творчо змагались учні дитячих музичних шкіл і навчальних закладів естетичного виховання. Переможцем, за одностайним рішенням журі, під головуванням Філіпа Віли, став учень центральної музичної школи Іван Огойко. У конкурсі серед вихованців вищих навчальних закладів перемогу здобув студент IV курсу Дніпропетровського музичного училища ім. М. Глінки Павло Пакшин. Також переможцями, лауреатами конкурсу-фестивалю стали гітаристи Дмитро Ваксер та Гліб Кіндзерський.

У той вечір зі сцени великої концертної зали консерваторії у супроводі Дніпропетровського філармонійного симфонічного оркестру, під орудою Наталії Понамарчук, у виконанні гітариста Філіпа Віли прозвучали два найпопулярніші концерти-шедеври для гітари $з$ оркестром, а саме - Концерт Ре-Мажор Антоніо Вівальді й концерт „Аранхуес” Хоакіно Родріго.

У заключний день Фестивалю відбулась творча зустріч із нашим гостем, відомим французьким гітаристом Філіпом Вілою. Він представив численні власні бачення щодо розвитку гітарного виконавства, зробив досить яскравий прискіпливий аналіз конкурсних виступів. Виконавець Філіп Віла провів також і майстер- 
класи з учнями музичних шкіл, зі студентами музичного училища, а також консерваторії.

Завершився черговий фестиваль урочистим нагородженням усіх переможців конкурсу, приємним врученням дипломів та спеціально підготовленого до цього Фестивалю-Ювілеїв цифрового видання, до якого увійшли архівні відео- та аудіо-записи, численні біографічні зібрання й ноти з творами Луїса де Нарваєса, Франческо Корбети, а також Василя Саренка.

Четвертий фестиваль ювілеїв (2017 р.) традиційно відкривався великим концертом, а саме - „Парад ювілярів”, у якому звучали твори Вінченцо Галілея і Томаса Кемпіона, Клаудіо Монтеверді та Філіппо Гран'яні, Енріке Гранадоса й Антоніо Лауро та, безумовно, Лауріндо Альмейди. Прізвища і твори композиторів, які лунали у концерті, ретроспективно розкривались у хронологічному порядку, завдячуючи чому, хоча і невеличкими штрихами й натяками, можна було спостерігати 500-річну динаміку еволюціонування європейської музики. Від поліфонії строгого стилю - до яскравих джазових мініатюр XX століття. Необхідно перерахувати усіх авторів, композиції, а також виконавців святкового концерту „Парад ювілярів".

Розпочався святковий концерт 3 виконання надзвичайно складного поліфонічного твору італійського композитора Вінченцо Галілея (нар. 1517) „In exitu Israhel”, що був виконаний Анною Міщенко (вокал) у супроводі квартету гітаристів. Далі 2-і меланхолійні канцони англійського лютняра й поета Томаса Кемпіона (нар. 1567) пролунали у чудовому виконанні тієї ж співачки Анни Міщенко. Три Скерцо написаних Клаудіо Монтеверді (нар. 1567) набули рис самобутніх танцювальних гуморесок XVI століття у яскравому втіленні зведеного ансамблю гітаристів 3 класу гітари Дніпропетровської академії музики ім. М. Глінки.

Не буде помилкою, якщо відзначимо, що вперше в Україні були виконані яскраві ансамблеві твори Філіппо Гран'яні (нар. 1767), спадщина якого досить повно означилась у концерті „Парад ювілярів". Прозвучали Скерцо для кларнета із супроводом гітари, Соната для скрипки й гітари, а також доволі масштабний твір квартет для скрипки, кларнета й 2-х гітар у чотирьох частинах, який блискуче виконали Ірина Осєнєва (скрипка), Валерій Громченко (кларнет), а також Юрій Радзецький і Антон Ялоза (гітари). 
Слід додати, що музику для кларнета у супроводі гітари, й залучення кларнета в камерні ансамблі за участю гітари - доволі рідкісне явище, а в нотній літературі саме класичної музики - взагалі унікальне.

У концерті звучали і композиції нового часу: Енріке Гранадоса (нар. 1867) та Антоніо Лауро (нар. 1917) й, безумовно, Лаурінди Алмейди (нар. 1917), які були виконані студентами класу гітари Свгеном Проданом і Тетяною Чайкою. Ми безмежно вдячні ветерану праці, надзвичайно завзятому ентузіасту музики вісімдесятирічному Едуарду Івановичу Авдоніну із Павлограда за активну участь у концерті й цікаву розповідь про венесуельського композитора Антоніо Лауро.

У рамках фестивалю провели й конкурс виконавців на класичній гітарі, де виконувались твори Вінченцо Галілея, Філіппо Гран'яні й Антоніо Лауро. Яскравими та духовно піднесеними переможцями конкурсу стали виконавці-гітаристи Семен Славич з Кривого Рогу, Анастасія Федотова, Олексій Терновий та Дмитро Ваксер - усі з міста Дніпра.

Після блискучих конкурсних прослуховувань у вечірньому концерті грав випускник академії музики ім. М. Глінки Дмитро Радзецький із прем'єрою нової музично-художньої програми „Radzetsky plays Radzetsky” - твори й композиції, цикли і сюїти сучасної музики для класичної гітари Юрія, а також Сергія й Дмитра Радзецьких.

Завершився Фестиваль Ювілеїв вишуканим нагородженням дипломантів і лауреатів. Усі учасники були дістались оригінальних дипломів, компакт-дисків із нотами й аудіо записами ювілярів: Вінченцо Галілей та Філіппо Гран'яні, а також Антоніо Лауро. Переможці конкурсу-фестивалю отримали дотого ж щей необхідну академічну гітарну атрибутику й комплекти професійних струн „D'Addario”.

П'ятий фестиваль ювілеїв (2019 р.). Герої П'ятого вже традиційного фестивалю Ювілеїв, який відбувся у березні цього року: відомі італійці-гітаристи Франческо Моліно (250 років від дня народження), знаний Фердінандо Карулі (250 років) та уславлений Луїджі Моцані (150 років від дня народження), а також український гітарист Марко Соколовський (200 років) й англієць Джон Дюарт (100 років від дня народження). Саме цим ювілярам та іншим видатним патріархам класичної гітари був присвячений яскравий 
великий концерт-відкриття фестивалю, а саме - Парад Ювілярів „Музика п'яти століть”, у якому були виконані численні твори вісімнадцяти композиторів. Програма широко охоплювала історію класичної гітари починаючи від XV століття.

У блискучому виконанні студентів саме класу гітари Дніпропетровської академії музики ім. М. Глінки, а це було сольне, ансамблеве, а також оркестрово-гітарне виконавство (ансамбль гітаристів 3 дванадцяти учасників), лунали п'єси, написані для лютні, віуели (це стародавній іспанський струнно-щипковий інструмент), ренесансної та барокової, класичної й романтичної гітар.

Своєрідну подяку висловлюємо концертмейстерові Тетяні Реві (Олександр Іванов-Крамський - Елегія й Антон Діабелі - Рондо), яскравій співачці Маріанні Цвєтінській (Джон Доуленд - Канцона) й талановитій флейтистці Софії Рзаєвій (Франческо Моліно - Ноктюрн) за винятково активну допомогу у підготовці програми й блискучий концертний виступ.

Друге відділення означилось композиціям сучасних авторів, лунала музика XX - XXI століть, яку яскраво й переконливо презентував заслужений артист України Володимир Доценко. Звучали композиції для гітари Мануеля де Фальї та Ейтора Віла Лобоса, Роланда Дієнса і Лео Брауера, Марека Пасічного й Ісато Накагави.

У наступний день фестивалю проходили конкурсні виступи учасників відкритого конкурсу виконавців-гітаристів. У трьох категоріях було заявлено аж сорок сім учасників, це виконавці із Дніпра, Кам'янського, Кривого Рогу, а також Оженина, Павлограда, Харкова, Тернополя, Перещепиного.

У творчому змаганні першої категорії, серед учнів дитячих музичних шкіл й навчальних закладів естетичного виховання, призером став Кравчук Ярослав із Кривого Рогу. У середній і старшій категоріях перші місця зайняли Анастасія Федотова i Анастасія Демчук (обидві учасниці з Дніпра).

Концерт електронно-акустичного гітарного дуету братів Сергія й Дмитра Радзецьких презентував знані інструментальні твори, прем'єри нових композицій та осучаснені версії-обробки музики уславлених композиторів ювілярів.

Певним сюрпризом для глядачів постав колективний номер 3 учнями-початківцями, вихованцями музичної школи 
Дніпропетровської академії музики ім. М. Глінки, а саме - Вікою Костенко, Мірою Губовою, а також Олексієм Міщенком.

Третій фестивальний день означився тривалим й змістовним майстер-класом професора Харківського національного університету мистецтв ім. І.П. Котляревського - Володимира Доценка.

Студенти й фахівці класичної гітари знайомі 3 високим гуманітарно-культурном та виконавським рівнем Володимира Доценка. Він постає провідним українським виконавцем на класичній гітарі, професійним академічним викладачем, саме тому майстер-клас був надзвичайно неупередженим та вкрай корисним. Володимир Доценко добре розуміє, що потрібно розповісти й проілюструвати, щоб фахівці якнайкраще усвідомили своєрідність та специфіку виконавства на класичній гітарі.

Завершився п'ятий Фестиваль Ювілеїв блискучим концертом „Стилістичні прем’єри”, в якому лунали твори для гітари з оркестром. Оригінальність й новизна були в тому, що гітарі акомпанував не симфонічний оркестр, а оркестр народних академічних інструментів під керівництвом Вікторії Кікас. Були виконані найпопулярніші гітарні концерти, а саме - Антоніо Вівальді (Концерт Ре-Мажор), виконавець Юрій Радзецький, Франческо Моліно (Концерт мі-мінор), виконавець Гліб Кіндзерський, „Фантазія для джентльмена” та Концерт „Аранхуес” Х. Родріго, які звучали у виконанні Анастасії Федотової й Антона Ялози. Уклінно дякуємо ведучій концерту, музикознавцеві Наталії Тарасовій.

У другому відділені святкового концерту пролунали творишедеври Ісаака Альбеніса та Леонарда Бернстайна, а також, підкреслимо, прем'єрний виступ оркестру народних академічних інструментів разом із тріо рок-музикантів: Дмитро Радзецький (MIDI-гітара), Сергій Радзецький (бас-гітара), Ростислав Ягідка (ударні).

У висновку треба додати, що проведення таких фестивалівювілеїв має вагоме значення у розширенні музичного i творчого світогляду як самих виконавців, так й викладачів, несе суттєве оновлення репертуару й відповідного жанрово-стильового розмаїття.

Конкурсні твори всіх п'яти фестивалів були відповідно відредаговані й надруковані. Наголосимо, що при складанні конкурсних виконавських програм міських, зональних, а також обласних творчих змагань серед гітаристів, майже третина виконуваних композицій „вийшла” із програм фестивалів-ювілеїв. 
Насамперед, це творча спадщина Вінченцо Галілея і Філіппо Гран'яні (твори-шедеври яких раніше взагалі рідко виконувались), Олександра Іванова-Крамського (до гітарної спадщини якого останнім часом мало звертались) та композиції Антоніо Лауро й Джона Доуленда, Луїса де Нарваєса i Франческо Моліно, Марка Соколовського та Луїджі Моцані й, безперечно, Джона Дюарта. 